\title{
How to make insulin-producing pancreatic $\beta$ cells for diabetes treatment
}

\author{
Jiaqi Lu ${ }^{1,2}$, Qing $\mathrm{Xia}^{1} \&$ Qiao $\mathrm{Zhou}^{2 *}$ \\ ${ }^{1}$ State Key Laboratory of Natural and Biomimetic Drugs, Department of Chemical Biology, Peking University School of Pharmaceutical \\ Sciences, Beijing 100191, China; \\ ${ }^{2}$ Department of Stem Cell and Regenerative Biology, Harvard Stem Cell Institute, Harvard University, Cambridge 02138, USA
}

Received July 24,2016; accepted September 20,2016; published online October 27, 2016

\begin{abstract}
Around 400 million people worldwide suffer from diabetes mellitus. The major pathological event for Type 1 diabetes and advanced Type 2 diabetes is loss or impairment of insulin-secreting $\beta$ cells of the pancreas. For the past 100 years, daily insulin injection has served as a life-saving treatment for these patients. However, insulin injection often cannot achieve full glucose control, and over time poor glucose control leads to severe complications and mortality. As an alternative treatment, islet transplantation has been demonstrated to effectively maintain glucose homeostasis in diabetic patients, but its wide application is limited by the scarcity of donated islets. Therefore, it is important to define new strategies to obtain functional human $\beta$ cells for transplantation therapies. Here, we summarize recent progress towards the production of $\beta$ cells in vitro from pluripotent stem cells or somatic cell types including $\alpha$ cells, pancreatic exocrine cells, gastrointestinal stem cells, fibroblasts and hepatocytes. We also discuss novel methods for optimizing $\beta$ cell transplantation and maintenance in vivo. From our perspective, the future of $\beta$ cell replacement therapy is very promising although it is still challenging to control differentiation of $\beta$ cells in vitro and to protect these cells from autoimmune attack in Type 1 diabetic patients. Overall, tremendous progress has been made in understanding $\beta$ cell differentiation and producing functional $\beta$ cells with different methods. In the coming years, we believe more clinical trials will be launched to move these technologies towards treatments to benefit diabetic patients.
\end{abstract}

pancreatic $\beta$ cell, diabetes mellitus, insulin, differentiation, reprogramming, iPSC, transplantation

Citation: Lu, J., Xia, Q., and Zhou, Q. (2017). How to make insulin-producing pancreatic $\beta$ cells for diabetes treatment. Sci China Life Sci 60, 239-248. doi: $10.1007 / \mathrm{s} 11427-016-0211-3$

\section{INTRODUCTION}

Diabetes mellitus is a metabolic disease that affects nearly 400 million people worldwide. Diabetic patients suffer from hyperglycemia due to a failure of glucose regulation (Shi and $\mathrm{Hu}, 2014)$ and are subject to a variety of complications such as retinopathy, kidney disease, cardiovascular disease, diabetic foot ulcers, diabetic enteropathy, and neuropathy (D'Addio et al., 2015). The islets of Langerhans, which

*Corresponding author (email: qiao_zhou@harvard.edu ) amount to $1 \%$ of the human pancreas, are clusters of endocrine cells that are responsible for closely controlling blood glucose levels. There are four major cell types in the islet: $\alpha$ cells, $\beta$ cells, $\delta$ cells, and pancreatic polypeptide (PP) cells. Of these, $\beta$ cells secret the glucose-lowing hormone insulin in response to high blood glucose, while $\alpha$ cells secrete glucose-elevating hormone glucagon when blood glucose is low.

Type 1 Diabetes (T1D) and Type 2 Diabetes (T2D) are the two major types of diabetes. T1D is characterized by $\beta$ cell destruction by the immune system, thus causing insufficient 
insulin production and increased blood glucose levels. T2D usually begins with peripheral insulin resistance, which progresses to persistent high blood glucose. In the advanced stages of T2D, $\beta$ cells can become dysfunctional, and may eventually be lost.

Insulin replacement therapy has been utilized for almost 100 years for T1D (Bruin et al., 2015b). However, even daily injections of insulin may not control blood glucose perfectly, sometimes resulting in hypoglycemia, ketosis and coma (DCCT/EDIC Research Group et al., 2009). T2D is commonly controlled by small-molecule drugs to promote $\beta$-cell function, to enhance insulin secretion and insulin sensitivity, and to facilitate glucose utilization. For advanced T2D patients, insulin therapy also becomes obligatory. Overall, it is difficult to achieve complete glucose control with insulin therapy for T1D and advanced T2D. Therefore, it is crucial to find new strategies to reverse hyperglycemia and alleviate the many debilitating complications of diabetes.

Insulin independence therapy was first performed in 2000 , when pancreatic islets isolated from human cadavers were transplanted into the liver of Type 1 Diabetic patients (Shapiro et al., 2000). Since then, more than 750 islet transplantations have been performed. Among the recipients, $44 \%$ could maintain normal blood glucose level without exogenous insulin supply for an extended period of time (Rekittke et al., 2016). However, widespread adoption of islet transplantation is not possible due to the shortage of cadaveric islet donors (Bellin et al., 2012). In response, many research groups have been developing novel technologies aimed at generating new functional $\beta$ cells that can be transplanted. These strategies have explored use of different cells and tissues, including pluripotent stem cells and somatic cells, to generate functional $\beta$ cells by treatment with genetic factors, small molecules, and growth factors (Figure 1). Furthermore, induction of $\beta$-cell replication may potentially generate more $\beta$ cells endogenously (Annes et al., 2012; Dor and Melton, 2004; Shen et al., 2013). Meanwhile, continuous efforts have been made to develop novel techniques to promote $\beta$-cell graft survival and maturation in vivo. Encapsulation technologies have also been improved to better protect $\beta$ cells from immune attack. Here we summarize the recent advances in $\beta$ cell generation and transplantation.

\section{GENERATING $\beta$ CELLS FROM PLURIPOTENT STEM CELLS IN VITRO}

In T1D patients, the majority of $\beta$ cells are lost to an autoimmune attack. In advanced T2D patients, the number of $\beta$ cells is often lower than comparable non-diabetic individuals (Rahier et al., 2008), and the function of the remaining $\beta$ cells is attenuated (Costes et al., 2013). Insulin injections and drug treatments only act to reverse hyperglycemia, and do not increase the number of $\beta$ cells. To tackle diabetes in diabetics of both types, perhaps the best strategy is to replenish the $\beta$ cell mass. But how can replacement $\beta$ cells be made?

One promising strategy is to derive $\beta$ cells from pluripotent stem cells. In the past 20 years, there have been several landmark achievements in stem cell derivation, differentiation, and reprogramming (Chari and Mao, 2016; Shiba et al., 2012). In 1998 Thomson et al. developed a method to successfully culture human embryonic stem cells (hESCs) which can generate all three germ layers and the associated cell

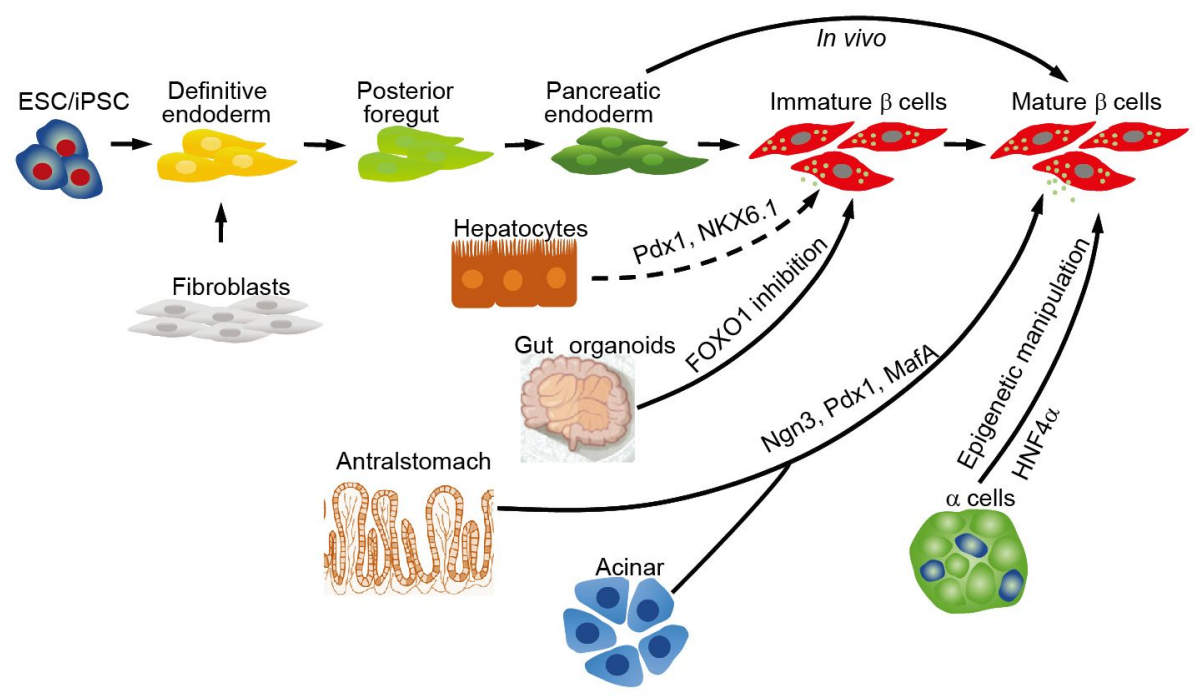

Figure 1 Strategies to generate functional $\beta$ cells. This diagram summarizes the different strategies used to generate functional insulin-secreting cells in animal models or with human cells. Directed differentiation using growth factors and small molecules can induce pluripotent stem cells (dark blue) into endoderm (yellow), posterior foregut (green), pancreatic progenitors (dark green) and $\beta$ cells (red). Reprogramming technologies have also been developed to generate $\beta$-like cells from multiple somatic cell sources, including pancreatic $\alpha$ cells, pancreatic acinar cells, hepatocytes, gut organoids, antral stomach cells and fibroblasts. Somatic cell reprogramming to $\beta$ cells requires different combinations of transcription factors and small molecules, depending upon the starting cell type. 
types (Thomson et al., 1998). In 2006 Takahashi and Yamanaka discovered the method to generate induced pluripotent stem cells (iPSCs) from murine fibroblasts with four transcriptional factors (Takahashi and Yamanaka, 2006). Since then, research on iPSCs generation from different types of human cells has been advancing at a remarkable pace (Chari and Mao, 2016; Takahashi and Yamanaka, 2016). In addition, a scalable system for producing functional pancreatic progenitors from human ESCs has been well-established and shown to reverse hyperglycemia after transplantation in mice (Rezania et al., 2012; Schulz et al., 2012). Therefore, human pluripotent stem cells, with their vast capacity for expansion and their ability to differentiate, are a very promising cell source for the production of new $\beta$ cells.

It has proved challenging to produce mature $\beta$ cells in vitro. Mature $\beta$ cells respond to increased glucose by secreting insulin, and turn off insulin secretion rapidly at lower glucose concentrations to avoid hypoglycemia. In the past decade, most differentiation protocols only managed to produce pancreatic endocrine progenitor cells or endocrine cells that co-express glucagon and insulin, but failed to generate mature $\beta$ cells in vitro (Bruin et al., 2014). It is very difficult to make mature $\mathrm{NKX}^{+} .1^{+} / \mathrm{MafA}^{+} \beta$ cells that only secrete insulin without producing glucagon and somatostatin (Bruin et al., 2013). In 1997 it was shown that when human fetal islet-like cell clusters were transplanted into mice, they matured into glucose-responsive insulin-secreting cells, which indicated that the pancreatic progenitors could differentiate further in vivo (Hayek and Beattie, 1997). In 2006, D'Amour et al. firstly differentiated human ESCs into hormone-expressing endocrine cells with limited glucose responsiveness, a phenotype similar to fetal $\beta$ cells (D'Amour et al., 2006). Then Kroon et al. successfully generated pancreatic endoderm from human ESCs that could be further differentiated into glucose-responsive insulin-secreting cells in vivo (Kroon et al., 2008). These cells had therapeutic potential because transplantation of these cells protected mice from streptozotocin (STZ)-induced hyperglycemia. In 2011, Kelly et al. further purified hESC-derived pancreatic cell cultures by FACS (fluorescence activated cell sorting) using CD142 as a marker. It was observed that CD142-enriched pancreatic endoderm cells were $\mathrm{PDX} 1^{+} / \mathrm{NKX} 6.1^{+} / \mathrm{PTF} 1 \mathrm{~A}^{+}$ pancreatic progenitors, which could generate pancreatic lineages in vivo (Kelly et al., 2011).

Significant advances have recently been made with regard to generating mature $\beta$-like cells from human pluripotent stem cells (Pagliuca et al., 2014). In 2014, Rezania et al. optimized a previously published six-stage protocol to make immature $\beta$ cells and built a seven-stage in vitro differentiation protocol for mature $\beta$ cells (Rezania et al., 2014). They first enhanced the production of $\mathrm{PDX} 1^{+} / \mathrm{NKX} 6.1^{+}$ pancreatic progenitors with low expression level of NGN3 by adding the antioxidant vitamin $\mathrm{C}$, which prevented the formation of polyhormonal cells induced by early expression of NGN3. The increase of glucose concentration from 10 to $20 \mathrm{mmol} \mathrm{L}^{-1}$ and the addition of ALK5 inhibitor, BMP receptor inhibitor and thyroid hormone (T3) to air-liquid interface (ALI) cultures enabled the differentiation of the pancreatic progenitors into pancreatic endocrine precursors. Further exposure to a Notch signaling pathway inhibitor shunted the cells toward immature $\beta$ cells $\left(\mathrm{PDX}^{+} / \mathrm{NKX}^{+} .1^{+} / \mathrm{NEUROD}^{+}\right.$) that still lack expression of MafA. In a subsequent screening of small molecules and growth factors, an inhibitor of the tyrosine kinase receptor AXL was found to induce MafA expression, producing the so-called mature $\beta$ cells derived from hESC. These cells were shown to possess functional similarities to human $\beta$ cells in terms of insulin content, glucose-stimulated human c-peptide secretion and ultrastructure of insulin granules, and they successfully reversed STZ-induced diabetes less than six weeks after transplantation under kidney capsule in immune-deficient mice. However, the calcium dynamics and insulin secretory kinetics were limited in the hESC-derived $\beta$ cells compared to human islets, and the long-term function and safety of these cells in vivo are still not clear.

Pagliuca et al. reported a similar differentiation protocol to generate $\beta$ cells in vitro from hESCs (Pagliuca et al., 2014). They applied a suspension-based culture system in contrast to the more traditional monolayer culture used in Rezania's protocol. Pagliuca's protocol added keratinocyte growth factor (KGF) from the definitive endoderm stage to the pancreatic progenitor stage. They also added ALK5 inhibitor, $\gamma$-secretase inhibitor, and heparin to induce pancreatic progenitor cell differentiation into pancreatic endocrine cells. Additionally, the epidermal growth factor receptor ligand betacellulin was added to promote and maintain the NKX6.1 expression level in the endocrine cells. Pagliuca et al. transplanted the stem cell-derived $\beta$ cells (SC- $\beta$ cells) under the kidney capsule and found that, two weeks after transplantation, eight out of 12 of mice had higher human insulin levels after a glucose challenge, which demonstrated that the in vivo function of SC- $\beta$ cells closely resemble human $\beta$ cells. Further, the SC- $\beta$ cells secreted higher levels of human insulin in response to three consecutive high glucose challenges, showing the potential of these cells to consistently function after transplantation. By measuring intracellular calcium flux, Pagliuca et al. also demonstrated that the SC- $\beta$ cells could respond to two to three sequential challenges, and they could flux calcium similarly to primary human islet cells. Despite these significant advances, the long-term survival and function of these cells in vivo remain to be fully determined.

The two studies discussed above opened the possibility for using hESC-derived $\beta$ cells to treat diabetes, which represents a significant step toward making a clinical impact with stem cell biology (Pagliuca et al., 2014). However, a report that $\sim 50 \%$ of the mice formed sporadic mesoderm after transplan- 
tation with these iPSCs-derived $\beta$ cells raises a cautionary note (Bruin et al., 2013). How well iPSCs can be differentiated into functional $\beta$ cells remains uncertain. One potential issue is that the epigenetic memory of iPSCs may affect their differentiation into $\beta$ cells. Bar-Nur et al. demonstrated that unlike other iPSCs, $\beta$ cell-derived iPSCs maintained open chromatin structure at key $\beta$ cell genes and possessed increased capacity to differentiate into $\beta$ cells compared with hESCs and isogenic non- $\beta$ cell-derived iPSCs (Bar-Nur et al., 2011). Thus, it is crucial to choose the right type of iPSCs for differentiation from the outset. Xie et al. used RNA-seq and ChIP-seq to further investigate the chromatin structure during $\mathrm{hESC}$ differentiation to pancreatic progenitors and then to endocrine cells in vivo (Xie et al., 2013). It was demonstrated that the chromatin of $\beta$ cell genes is differently remodeled during $\beta$ cell differentiation in vitro. By systematic labeling of key developmental genes at different differentiation stages, Liu et al. identified a novel surface protein, SUSD2 (Sushi domain containing 2) as a marker that permitted the enrichment of pancreatic endocrine progenitor cells in hESC-derived pancreatic cell cultures and in the developing human pancreas (Liu et al., 2014). Transplantation of SUSD2-enriched cell populations could provide a better way to get mature $\beta$ cells after transplantation in mice (Liu et al., 2014). Thus from the clinical perspective, optimization of these published protocols is necessary.

In the past years, significant advances have been made to regulate pancreatic differentiation of human pluripotent stem cells (hPSCs) by modulating signal pathways, including retinoic acid, Wnt, bone morphogenic protein (BMP), fibroblast growth factor (FGF), Notch, transforming growth factor $\beta$ (TGF- $\beta$ ) and sonic hedgehog (SHH) signaling pathways (Nostro and Keller, 2012; Nostro et al., 2011). Nostro et al. demonstrated that the combination of epidermal growth factor (EGF) and nicotinamide signaling induced the development of NKX6.1 $1^{+}$progenitors from hPSCs. The induced NKX6. $1^{+}$progenitors were capable of differentiating into insulin-secreting cells after transplantation into immunodeficient mice (Nostro et al., 2015). Russ et al. discovered that BMP inhibition resulted in precocious induction of endocrine differentiation in $\mathrm{PDX}^{+}$pancreatic progenitors, which generated non-functional poly-hormonal cells, and omission of BMP inhibitors could prevent precocious endocrine formation and effectively generate functional human $\beta$-like cells (Russ et al., 2015). Precisely, dynamic temporal regulation of TGF- $\beta$ signaling is required for differentiation of hESC into $\beta$ cells because TGF- $\beta$ ligands strongly inhibit endocrine differentiation from progenitors, although these TGF- $\beta$ ligands significantly induce pancreatic progenitors formation (Guo et al., 2013). Thus TGF- $\beta$ ligand treatment followed by TGF- $\beta$ receptor antagonist addition can increase insulin-producing cells in pancreatic differentiation in vitro (Guo et al., 2013). Altogether, optimal stage-specific manip- ulation of these signaling pathways is necessary for effective generation of functional $\beta$ cells from hPSC.

\section{REPROGRAMMING SOMATIC CELLS INTO $\beta$ CELLS}

Pluripotent stem cells are not the only source to make $\beta$ cells. In recent years, direct reprogramming (also known as transdifferentiation, or direct lineage conversion) of different somatic cell types to $\beta$ cells has shown great promise.

\section{$\alpha$ to $\beta$ cell reprogramming}

Glucagon-secreting $\alpha$ cells share a close lineage relationship with $\beta$ cells. It has been shown that $\alpha$ cells harbor bivalent chromatin signatures at $\beta$ cell-specific genes, and under experimental conditions where most of the $\beta$ cells are destroyed by diphtheria toxin-mediated ablation, mouse $\alpha$ cells can generate insulin ${ }^{+}$cells (Thorel et al., 2010). It is unclear, however, as to how closely the new $\beta$ cells resemble endogenous $\beta$ cells in terms of their molecular characteristics and function. In addition, loss of $\beta$ cells by other methods, such as streptozotocin treatment, does not elicit this conversion event. Overall, the mechanism of this conversion and whether it occurs under physiological conditions remain unclear.

PAX4 was shown to promote differentiation of mouse pancreatic progenitor cells into $\alpha$ cells and subsequently to $\beta$ cells (Collombat et al., 2009). However, Chen et al. argued that PAX4 expression didn't induce significant $\alpha$ to $\beta$ cell conversion (Chen et al., 2015). Thus it is still debatable as to whether PAX4 alone can promote $\alpha$ to $\beta$ cell reprogramming. In 2011, Yang et al. found that forced expression of PDX1 in the $\mathrm{NGN}^{+}$endocrine progenitor stage could facilitate $\alpha$ to $\beta$ cell conversion (Yang et al., 2011). Another study revealed that inactivation of $A r x$ in pancreatic $\alpha$ cells is sufficient to promote the conversion of adult $\alpha$ cells into $\beta$-like cells (Courtney et al., 2013). Caroline et al. discovered that forced expression of HNF4 $\alpha$ could reprogram pancreatic $\alpha$ cell line $\alpha \mathrm{TC1}-9$ to insulin ${ }^{+}$cells (Sangan et al., 2015). Moreover, epigenetic manipulation can also facilitate $\alpha$ to $\beta$ cell reprogramming. Bramswig et al. treated $\alpha$ cells with Adox, a histone methyltransferase inhibitor, and achieved partial conversion to insulin ${ }^{+}$cells (Bramswig et al., 2013). Recently it was observed that Activin enhanced $\alpha$ to $\beta$ cell reprogramming (Brown et al., 2016), indicating that signaling regulation may contribute to $\alpha$ to $\beta$ cell reprogramming.

\section{Pancreatic exocrine cell to $\beta$ cell reprogramming}

Ductal cells and acinar cells are the main cell types of pancreatic exocrine tissue. Acinar cells synthesize and secret numerous digestive enzymes. In 2008, it was reported that mouse acinar cells could be converted to $\beta$ cells in vivo by viral expression of three transcription factors (NPM factors), Ngn3, Pdx1 and MafA (Zhou et al., 2008). This study was the 
first to confirm that $\beta$ cells could be generated from mouse pancreatic exocrine cells. Moreover, $\alpha$-like and $\delta$-like endocrine cells were successfully derived from mouse acinar cells by expression of NGN3 + MafAand NGN3 respectively, which indicates that the three major islet endocrine cell types can be generated via acinar reprogramming (Pagliuca et al., 2014). Subsequently, $\beta$ cells were induced by an improved method, with polycistronic expression of the NPM factors, and the long-term effects of the acinar-derived $\beta$ cells were evaluated (Li et al., 2014). It was discovered the functional $\beta$ cells could persist for up to 13 months in mice. Furthermore, hyperglycemia was found to attenuate in vivo reprogramming of pancreatic exocrine cells to $\beta$ cells in mice (Cavelti-Weder et al., 2016). However, whether these three transcription factors are sufficient to induce $\beta$ cells from acinar cells in human tissue is unknown.

In 2013, human ductal cells converted into $\beta$ cells via forced expression of NPM factors together with Pax6 (Lee et al., 2013). As the PAX4-mediated $\alpha$ to $\beta$-like cell conversion, pancreatic duct-lining cells can reprogram into $\beta$-like cells which are able to mitigate diabetes (Al-Hasani et al., 2013). Recently it was found that $2 \%$ of ductal and acinar cells in adult human pancreas express NGN3, and that differentiation of these $\mathrm{NGN}^{+}$cells could give rise to C-peptide ${ }^{+} /$Chromogranin $\mathrm{A}^{+} / \mathrm{PDX}^{+}$endocrine cells that resemble $\beta$ cells (Gomez et al., 2015). Meanwhile, another study described a method to convert a sub-population of human non-endocrine pancreatic tissue to insulin-secreting endocrine cells with a single growth factor, BMP7 (Klein et al., 2015), thus demonstrating that transcription factor-free methods can potentially be applied to make $\beta$ cells from pancreatic exocrine tissue. In 2016, a combination of cytokines including epidermal growth factor (EGF) and ciliary neurotrophic (CNTF) was shown to restore functional $\beta$ cell mass by reprogramming acinar cells that transiently expressed NGN3 in mice with hyperglycaemia, which enable development of new insights into fate re-specification of acinar cells in diabetes (Lemper et al., 2016).

\section{Gastrointestinal tissues to $\beta$ cell reprogramming}

Among endodermal tissues, the gastrointestinal epithelium is a highly regenerative tissue harboring large numbers of adult stem cells and progenitors that can generate hormone-secreting enteroendocrine cells (Drost et al., 2015; Gregorieff and Clevers, 2015; Hoffmann, 2015; Mills and Shivdasani, 2011). For example the $\mathrm{Lgr}^{+}$stem cells drive self-renewal in the stomach, and can build gastric organoids in vitro (Barker et al., 2010). In 2012 Talchai et al. generated insulin-producing cells from gut tissue by Foxo1 ablation in $\mathrm{Ngn}^{+}$ endocrine progenitors (Talchai et al., 2012). Subsequently Bouchi et al. yielded functional insulin-producing cells from human gut organoid culture through Foxo1 inhibition (Bouchi et al., 2014), showing that intestinal tissue could serve as a regenerative source for producing $\beta$ cells. However, the deletion or suppression of Foxo1 has been shown to cause $\beta$ cell failure, possibly due to Foxo1's ability to protect against $\beta$ cell dysfunction through the induction of NeuroD and MafA (Kitamura et al., 2005). Thus, from the therapeutic perspective, it may not be feasible to generate $\beta$ cells by inhibiting Foxo1. Intestinal $\mathrm{K}$ cells have been engineered to produce insulin, which protect non-obese diabetic mice from autoimmune diabetes (Mojibian et al., 2014).

In 2014 , Chen et al. showed generation of "neo- $\beta$ cell islets" from intestinal crypts by knocking in NPM factors (Chen et al., 2014) but the induced $\beta$ cells lacked important $\beta$ cell markers such as NKX6.1 and prohormone convertase 2 (PC2) and exhibited limited insulin secretion upon glucose stimulation. Thus it is crucial to generate more efficient insulin-producing cells using highly regenerative tissues as a renewable source of $\beta$ cells. Recently, Ariyachet et al. reported the transcriptional similarity between cells of the antral stomach and $\beta$ cells (Ariyachet et al., 2016). This study validated that reprogramming stomach organoids represented a renewable cell source that could be reprogrammed into $\beta$ cells and that were capable of rescuing hyperglycemia when transplanted into diabetic mice (Ariyachet et al., 2016). Compared to the intestinal enteroendocrine cells, the antral enteroendocrine cells share more transcriptional similarity with $\beta$ cells. The induced antral insulin cells expressed key $\beta$ cell markers, including NKX6.1, NKX2.2 and PC2, which are not expressed in the insulin-producing cells derived from intestine. Moreover, the reprogrammed stomach cells included abundant $\mathrm{SOX9}^{+}$and $\mathrm{Ki}^{+} 7^{+}$cells, suggesting their high regenerative capacity and potential for clinical application to avoid repeated transplantation. Ariyachet's study is the first to show that NPM-engineered antral stomach could potentially be used to treat diabetes.

\section{Hepatocyte to $\boldsymbol{\beta}$ cell reprogramming}

Liver and pancreas are believed to originate from a common precursor. The first demonstration of liver to pancreatic lineage reprogramming was achieved with ectopic expression of PDX1 in mice (Ferber et al., 2000). With a similar strategy, Sapir et al. reprogrammed human adult liver cells to insulin-producing cells in vitro, which successfully reversed hyperglycemia after transplantation in vivo (Sapir et al., 2005). Since then, numerous studies improved the efficiency of liver to pancreas reprogramming by co-expressing PDX1 with pancreatic transcription factors, including NeuroD, NGN3, MafA, and Pax4 (Ham et al., 2013; Tang et al., 2006; Yatoh et al., 2007). The cells generated appear to resemble pancreatic endocrine cells that were marked by insulin, glucagon and somatostatin, and were $\beta$-cell lineage. In 2010 Gefen-Halevi et al. found that co-expression of PDX1 with NKX6.1 could specifically induce liver cells into $\beta$ cells by increasing insulin production and repressing glucagon ex- 
pression (Gefen-Halevi et al., 2010). Meivar-Levy et al. further identified that the insulin-secreting cells originated from the human liver cells that co-expressed albumin and mesenchymal characteristics (Meivar-Levy et al., 2011). Qiwei Wang et al. successfully derived pancreatic progenitor-like cells (PPCs) from rat hepatic cells and further induced these PPCs into pancreatic $\beta$-like cells (Wang et al., 2013). These studies offer encouraging evidence that primary culture of adult liver cells may possess the ability to serve as the basis for a cell replacement therapy for diabetes.

\section{$\beta$ cell regeneration by replication}

Another strategy is to generate more $\beta$ cells endogenously from existing $\beta$ cells. It was reported that $16 \%$ of young Type 1 diabetes patients have detectable C-peptide levels (Scholin et al., 2004), indicating that a small number of $\beta$ cells exist in some diabetes patients, which could be potentially used as a source for new $\beta$ cells. To stimulate $\beta$ cell proliferation, a variety of small molecules have been tested and identified, including glucagon-like peptide 1 receptor agonist (Xu et al., 1999), cAMP-stabilizing reagents (Zhao et al., 2014), and adenosine kinase inhibitors (Annes et al., 2012). Recently a high-content screening system was established to identify $\beta$-cell replication-promoting small molecules in primary cell culture (Zhao et al., 2016). These efforts suggest that expansion of endogenous $\beta$-cell might be a promising strategy to treat diabetes.

\section{Fibroblast to $\beta$ cell reprogramming}

A recent report described a new method to derive $\beta$ cells from fibroblasts that potentially bypasses a pluripotent reprogramming step (Zhu et al., 2016). The study exploited non-integrative episomal reprogramming factors, together with growth factors and chemical compounds to generate endodermal progenitor cells directly from human foreskin fibroblasts. Then posterior foregut-like progenitors (cPF) and pancreatic endodermal progenitor cells (cPE) were induced and further expanded by a group of growth factors and compounds. Finally the differentiation from $\mathrm{cPE}$ cells to functional pancreatic $\beta$ cells was achieved, and the induced $\beta$ cells were able to lower blood glucose level in diabetic mice. Thus, Zhu et al. discovered a method for large scale production of pancreatic $\beta$ cells from fibroblasts and presented evidence that the reprogrammed cells do not pass through a pluripotent stage. However, Bar-Nur et al. and Maza et al. argued that when somatic cells are reprogrammed using iPSC reprogramming factors, the majority of somatic cells must pass through a transient pluripotent state marked by OCT4 expression and reactivation of silenced X chromosomes, suggesting that it is not entirely clear whether the fibroblasts transited through a brief pluripotent stage prior to $\beta$ cell reprogramming (Bar-Nur et al., 2015; Maza et al., 2015).
Overall, significant progress has been made in reprogramming various somatic cell types to insulin ${ }^{+}$cells. Most of these studies were carried out in animal models. The next major challenge is to apply these reprogramming methods to human cells. As with all efforts to generate or regenerate $\beta$ cells, it is critical that comprehensive functional, molecular, and epigenetic studies are carried out to thoroughly evaluate the new $\beta$ cells and compare their properties with endogenous pancreatic $\beta$ cells. Such in-depth analyses are absolutely essential and have been conducted only in a small number of cases so far.

\section{TRANSPLANTATION AND $\beta$ CELL SURVIVAL IN VIVO}

One big challenge in cell replacement therapy for Type $1 \mathrm{Di}-$ abetes is to maintain graft function in patients over the long term after $\beta$ cell transplantation. To achieve a high survival rate and sustained glucose responsiveness of the transplanted $\beta$ cells in vivo, several major issues need to be tackled, which include: (i) accelerating the maturation of the transplanted cells in vivo, (ii) finding an optimal transplantation site in human body, (iii) protecting $\beta$ cells from autoimmune attack and inflammatory reactions, (iv) facilitating the vascularization of the transplanted $\beta$ cells and the insulin release from the graft.

Experimental islet transplantations have been performed in liver, kidney capsule, spleen, omental pouch, muscle, pancreas, lung, stomach, subcutaneous sites, and many immunoprivileged locations such as thymus and testes of various animal models, among which kidney capsule is the major site in diabetic mouse models (Merani et al., 2008). In human, liver is the current transplantation site. However, intrahepatic transplantation often results in acute or gradual graft attrition and may lead to bleeding and thrombosis. An optimal site for transplantation should have enough tissue volume capacity and sufficient blood supply to enable the transplantation of a large numbers of cells and maintenance of their function in vivo. The pancreas itself is not a good transplantation site due to the risk of pancreatitis. The intraperitoneal space and omental pouch are potential attractive places to transplant because they can harbor large volumes of tissue and/or devices, and blood vessels can easily form around the graft (Wahoff et al., 1994). Intramuscular transplantation is also reasonable owing to the comparatively easy surgical process and the highly vascular nature of muscle (Sakata et al., 2014). Compared to portal vein infusion and the other transplantation sites discussed above, subcutaneous transplantation is the easiest in terms of the surgical procedure. Retrieval of the graft is also possible under skin. In 1994, subcutaneous transplantation of macro-encapsulated human islets resulted in $\beta$ cell survival and insulin secretion upon glucose stimulation of the graft, thus providing a possible method to transplant 
$\beta$ cell into the human body (Scharp et al., 1994). However, subcutaneous islet transplants suffer from poor oxygen supply and insufficient vessel formation. The ongoing phase $1 / 2$ clinical trial by Viacyte (NCT02239354) aims to test whether hESC-derived pancreatic progenitors can be implanted subcutaneously and maintain safely for two years in Type 1 Diabetes patients. Maturation of transplanted pancreatic progenitor cells is another critical issue. It has been reported that chronic hyperglycemia accelerates the maturation of transplanted progenitor cells under the kidney capsule in mice. In contrast, insulin treatment, anti-diabetic drug treatment, or high-fat diets did not appear to affect the maturation in vivo (Bruin et al., 2015c). For pancreatic progenitor cells, allowing the cells to aggregate before transplantation is crucial, and transplanted single cells fail to mature into insulin-producing cells in vivo (Beattie et al., 1996). In 2013, a Theracyte macro-encapsulation device was adopted by Bruin et al. to create a cell-isolation environment to protect the cells from immune attack (Bruin et al., 2013). The important advance of this research is that they generated the macro-encapsulated endocrine tissue by a revised protocol, which effectively prevented the progenitors from differentiating into non-pancreatic cell types and pancreatic exocrine tissue. Recently Bruin et al. found that the progenitors mature faster in nude rats than in the immunodeficient mice (Bruin et al., 2015a), which reveals that the recipient affects the maturation of progenitors in vivo. Long-term glycemic control in a diabetic and immunocompetent animal model has been achieved by encapsulating stem cell-derived $\beta$ cells with alginate derivatives capable of mitigating foreign-body responses in vivo (Vegas et al., 2016). The implants minimized the host immune responses and maintained the glucose level without any immunosuppression.

Vascularization is the major factor that determines whether the transplanted graft can respond to the glucose fluctuations in vivo. A variety of growth factors have been added to the transplanted graft microenvironment to stimulate angiogenesis in the subcutaneous site. These include vascular endothelial growth factor (VEGF), fibroblast growth factor (FGF) and hepatocyte growth factor (HGF). Moreover, multiple devices have been transplanted together with tissues, including encapsulation devices, matrices, meshes, hydrogels and polymers to improve the vessel formation around the graft (Pepper et al., 2015; Zhang et al., 2013). These biomaterials often cause inflammatory reactions that induce macrophages to form foreign-body giant cells, which secret signaling molecules and promote neovascularization in the early stages but later they can induce the formation of a collagenous fibrotic capsule around the implant that isolates it from the host (Anderson et al., 2008). Recently Pepper et al. developed a novel method to control this innate foreign-body response by inducing neovascularization with a subcutaneously transplanted hollow nylon catheter for one month prior to islet transplantation in the device-less site (Pepper et al., 2015). In this way, diabetes could be reversed without a permanent encapsulation device or growth factors. However, the transplantation should be done before the formation of the fibrotic scar in this method, or the metabolic exchange between the graft and the host will be hindered by the fibrotic scar. This approach also opens up the possibility of noninvasive imaging to monitor graft survival when applied to human while the currently used portal vein infusion is incompatible with real-time observation.

\section{CHALLENGES AND PERSPECTIVES}

In the past 10 years multiple methods were developed to generate insulin-secreting cells that can reverse diabetes after transplantation. These $\beta$ cells provide a useful model for anti-diabetic drug screening and toxicology testing. Many of the published studies thus far were carried out with animal cells; it is unclear, therefore, how readily these technologies can be translated to human cells and tissues (Nair and Hebrok, 2015). For clinical application in humans, the use of patient-specific iPSCs as a cell source to derive $\beta$ cells will enable avoidance of allograft rejection. Significant progress has been made with respect to ESC- and iPSC-derived $\beta$ cells, although their long-term function post-transplantation needs to be further evaluated and new methods are required to further purify the stem cell-derived $\beta$ cells to prevent formation of cysts or tumors. For $\beta$ cells derived from somatic progenitor cells or differentiated cell types via reprogramming, a major challenge is to deliver genetic factors with virus-free and integration-free methods to make them clinically suitable.

Another critical issue that has to be further studied is whether transplanting pure $\beta$ cells will have similar functional outcomes to transplanting pancreatic tissues that contain all types of pancreatic endocrine cells $(\delta, \alpha, p p$ cells), as the other islet cell types play important roles in fine tuning $\beta$ cell function and glucose regulation. Furthermore, inclusion of cell types such as the mesenchymal or endothelial cells may facilitate long-term engraftment of $\beta$ cells in vivo (Quaranta et al., 2014). Overall, numerous efforts have been made to generate mature and functional $\beta$ cells in vitro and in vivo. Environmental triggers and the genetic susceptibility for diabetes could affect the efficiency of the cell replacement therapy. Careful testing of safety and efficacy of these approaches for diabetes is also needed. Despite these challenges, generation of autologous human $\beta$ cells presents a very promising future for the treatment of diabetes.

Compliance and ethics The author(s) declare that they have no conflict of interest.

Al-Hasani, K., Pfeifer, A., Courtney, M., Ben-Othman, N., Gjernes, E., Vieira, A., Druelle, N., Avolio, F., Ravassard, P., Leuckx, G., 
Lacas-Gervais, S., Ambrosetti, D., Benizri, E., Hecksher-Sorensen, J., Gounon, P., Ferrer, J., Gradwohl, G., Heimberg, H., Mansouri, A., and Collombat, P. (2013). Adult duct-lining cells can reprogram into $\beta$-like cells able to counter repeated cycles of toxin-induced diabetes. Dev Cell 26, 86-100.

Anderson, J.M., Rodriguez, A., and Chang, D.T. (2008). Foreign body reaction to biomaterials. Seminars Immunol 20, 86-100.

Annes, J.P., Hyoje Ryu, J., Lam, K., Carolan, P.J., Utz, K., Hollister-Lock, J., Arvanites, A.C., Rubin, L.L., Weir, G., and Melton, D.A. (2012). Adenosine kinase inhibition selectively promotes rodent and porcine islet $\beta$-cell replication. Proc Natl Acad Sci USA 109, 3915-3920.

Ariyachet, C., Tovaglieri, A., Xiang, G., Lu, J., Shah, M.S., Richmond, C.A., Verbeke, C., Melton, D.A., Stanger, B.Z., Mooney, D., Shivdasani, R.A., Mahony, S., Xia, Q., Breault, D.T., and Zhou, Q. (2016). Reprogrammed stomach tissue as a renewable source of functional $\beta$ cells for blood glucose regulation. Cell Stem Cell 18, 410-421.

Bar-Nur, O., Russ, H.A., Efrat, S., and Benvenisty, N. (2011). Epigenetic memory and preferential lineage-specific differentiation in induced pluripotent stem cells derived from human pancreatic islet beta cells. Cell Stem Cell 9, 17-23.

Bar-Nur, O., Verheul, C., Sommer, A.G., Brumbaugh, J., Schwarz, B.A., Lipchina, I., Huebner, A.J., Mostoslavsky, G., and Hochedlinger, K. (2015). Lineage conversion induced by pluripotency factors involves transient passage through an iPSC stage. Nat Biotechnol 33, 761-768.

Barker, N., Huch, M., Kujala, P., van de Wetering, M., Snippert, H.J., van Es, J.H., Sato, T., Stange, D.E., Begthel, H., van den Born, M., Danenberg, E., van den Brink, S., Korving, J., Abo, A., Peters, P.J., Wright, N., Poulsom, R., and Clevers, H. (2010). Lgr5 ${ }^{\text {tve }}$ stem cells drive self-renewal in the stomach and build long-lived gastric units in vitro. Cell Stem Cell 6, 25-36.

Beattie, G.M., Rubin, J.S., Mally, M.I., Otonkoski, T., and Hayek, A. (1996). Regulation of proliferation and differentiation of human fetal pancreatic islet cells by extracellular matrix, hepatocyte growth factor, and cell-cell contact. Diabetes 45, 1223-1228.

Bellin, M.D., Barton, F.B., Heitman, A., Harmon, J.V., Kandaswamy, R., Balamurugan, A.N., Sutherland, D.E.R., Alejandro, R., and Hering, B.J. (2012). Potent induction immunotherapy promotes long-term insulin independence after islet transplantation in type 1 diabetes. Am J Transplant $12,1576-1583$.

Bouchi, R., Foo, K.S., Hua, H., Tsuchiya, K., Ohmura, Y., Sandoval, P.R., Ratner, L.E., Egli, D., Leibel, R.L., and Accili, D. (2014). FOXO1 inhibition yields functional insulin-producing cells in human gut organoid cultures. Nat Commun 5, 4242.

Bramswig, N.C., Everett, L.J., Schug, J., Dorrell, C., Liu, C., Luo, Y., Streeter, P.R., Naji, A., Grompe, M., and Kaestner, K.H. (2013). Epigenomic plasticity enables human pancreatic $\alpha$ to $\beta$ cell reprogramming. J Clin Invest 123, 1275-1284.

Brown, M.L., Andrzejewski, D., Burnside, A., and Schneyer, A.L. (2016). Activin enhances $\alpha$ - to $\beta$-cell transdifferentiation as a source for $\beta$-cells in male FSTL3 knockout mice. Endocrinology 157, 1043-1054.

Bruin, J.E., Asadi, A., Fox, J.K., Erener, S., Rezania, A., and Kieffer, T.J. (2015a). Accelerated maturation of human stem cell-derived pancreatic progenitor cells into insulin-secreting cells in immunodeficient rats relative to mice. Stem Cell Rep 5, 1081-1096.

Bruin, J.E., Erener, S., Vela, J., Hu, X., Johnson, J.D., Kurata, H.T., Lynn, F.C., Piret, J.M., Asadi, A., Rezania, A., and Kieffer, T.J. (2014). Characterization of polyhormonal insulin-producing cells derived in vitro from human embryonic stem cells. Stem Cell Res 12, 194-208.

Bruin, J.E., Rezania, A., and Kieffer, T.J. (2015b). Replacing and safeguarding pancreatic $\beta$ cells for diabetes. Sci Transl Med 7, 316ps23-316ps23.

Bruin, J.E., Rezania, A., Xu, J., Narayan, K., Fox, J.K., O’Neil, J.J., and Kieffer, T.J. (2013). Maturation and function of human embryonic stem cell-derived pancreatic progenitors in macroencapsulation devices following transplant into mice. Diabetologia 56, 1987-1998.

Bruin, J.E., Saber, N., Braun, N., Fox, J.K., Mojibian, M., Asadi, A., Drohan, C., O’Dwyer, S., Rosman-Balzer, D.S., Swiss, V.A., Rezania, A., and Kieffer, T.J. (2015c). Treating diet-induced diabetes and obesity with human embryonic stem cell-derived pancreatic progenitor cells and antidiabetic drugs. Stem Cell Rep 4, 605-620.

Cavelti-Weder, C., Li, W., Zumsteg, A., Stemann-Andersen, M., Zhang, Y., Yamada, T., Wang, M., Lu, J., Jermendy, A., Bee, Y.M., Bonner-Weir, S., Weir, G.C., and Zhou, Q. (2016). Hyperglycaemia attenuates in vivo reprogramming of pancreatic exocrine cells to beta cells in mice. Diabetologia 59, 522-532.

Chari, S., and Mao, S. (2016). Timeline: iPSCs - the first decade. Cell Stem Cell 18, 294.

Chen, L., Zhang, J., Zhang, Z., Chu, Y., Song, B., and Cai, W. (2015). Pax4 expression does not transduce pancreatic alpha cells to beta cells. Cell Physiol Biochem 36, 1735-1742.

Chen, Y.J., Finkbeiner, S.R., Weinblatt, D., Emmett, M.J., Tameire, F., Yousefi, M., Yang, C., Maehr, R., Zhou, Q., Shemer, R., Dor, Y., Li, C., Spence, J.R., and Stanger, B.Z. (2014). De novo formation of insulin-producing "neo- $\beta$ cell islets" from intestinal crypts. Cell Rep 6, $1046-1058$.

Collombat, P., Xu, X., Ravassard, P., Sosa-Pineda, B., Dussaud, S., Billestrup, N., Madsen, O.D., Serup, P., Heimberg, H., and Mansouri, A. (2009). The ectopic expression of Pax4 in the mouse pancreas converts progenitor cells into $\alpha$ and subsequently $\beta$ cells. Cell 138, 449-462.

Costes, S., Langen, R., Gurlo, T., Matveyenko, A.V., and Butler, P.C. (2013). $\beta$-Cell failure in type 2 diabetes: a case of asking too much of too few? Diabetes 62, 327-335.

Courtney, M., Gjernes, E., Druelle, N.Ã., Ravaud, C., Vieira, A., Ben-Othman, N., Pfeifer, A., Avolio, F., Leuckx, G., Lacas-Gervais, S., Burel-Vandenbos, F., Ambrosetti, D., Hecksher-Sorensen, J., Ravassard, P., Heimberg, H., Mansouri, A., Collombat, P., and Habener, J. (2013). The inactivation of Arx in pancreatic $\alpha$-cells triggers their neogenesis and conversion into functional $\beta$-like cells. PLoS Genet 9, e1003934.

D'Amour, K.A., Bang, A.G., Eliazer, S., Kelly, O.G., Agulnick, A.D., Smart, N.G., Moorman, M.A., Kroon, E., Carpenter, M.K., and Baetge, E.E. (2006). Production of pancreatic hormone-expressing endocrine cells from human embryonic stem cells. Nat Biotechnol 24, 1392-1401.

D’Addio, F., La Rosa, S., Maestroni, A., Jung, P., Orsenigo, E., Ben Nasr, M., Tezza, S., Bassi, R., Finzi, G., Marando, A., Vergani, A., Frego, R., Albarello, L., Andolfo, A., Manuguerra, R., Viale, E., Staudacher, C., Corradi, D., Batlle, E., Breault, D., Secchi, A., Folli, F., and Fiorina, P. (2015). Circulating IGF-I and IGFBP3 levels control human colonic stem cell function and are disrupted in diabetic enteropathy. Cell Stem Cell 17, 486-498.

Diabetes Control and Complications Trial/Epidemiology of Diabetes Interventions and Complications (DCCT/EDIC) Research Group., Nathan, D.M., Zinman, B., Cleary, P.A., Backlund, J.Y., Genuth, S., Miller, R., and Orchard, T.J. (2009). Modern-day clinical course of type 1 diabetes mellitus after 30 years' duration. Arch Intern Med 169, 1307-1316.

Dor, Y., and Melton, D.A. (2004). How important are adult stem cells for tissue maintenance. Cell Cycle 3, 1104-1106.

Drost, J., van Jaarsveld, R.H., Ponsioen, B., Zimberlin, C., van Boxtel, R., Buijs, A., Sachs, N., Overmeer, R.M., Offerhaus, G.J., Begthel, H., Korving, J., van de Wetering, M., Schwank, G., Logtenberg, M., Cuppen, E., Snippert, H.J., Medema, J.P., Kops, G.J.P.L., and Clevers, H. (2015). Sequential cancer mutations in cultured human intestinal stem cells. Nature 521, 43-47.

Ferber, S., Halkin, A., Cohen, H., Ber, I., Einav, Y., Goldberg, I., Barshack, I., Seijffers, R., Kopolovic, J., Kaiser, N., and Karasik, A. (2000). Pancreatic and duodenal homeobox gene 1 induces expression of insulin genes in liver and ameliorates streptozotocin-induced hyperglycemia. Nat Med $6,568-572$.

Gefen-Halevi, S., Rachmut, I.H., Molakandov, K., Berneman, D., Mor, E., Meivar-Levy, I., and Ferber, S. (2010). NKX6.1 promotes PDX-1-induced liver to pancreatic $\beta$-cells reprogramming. Cell Reprogram 12, 655-664.

Gregorieff, A., and Clevers, H. (2015). In situ hybridization to identify gut stem cells. Curr Protoc Stem Cell Biol 34, 2F.1.1-2F.1.11 . 
Guo, T., Landsman, L., Li, N., and Hebrok, M. (2013). Factors expressed by murine embryonic pancreatic mesenchyme enhance generation of insulin-producing cells from hESCs. Diabetes 62, 1581-1592.

Ham, D.S., Shin, J., Kim, J.W., Park, H.S., Cho, J.H., Yoon, K.H., and Maedler, K. (2013). Generation of functional insulin-producing cells from neonatal porcine liver-derived cells by PDX1/VP16, BETA2/NeuroD and MafA. PLoS ONE 8, e79076.

Hayek, A., and Beattie, G.M. (1997). Processing, storage and experimental transplantation of human fetal pancreatic cells. Ann Transplant 2, 46-54.

Hoffmann, W. (2015). Current status on stem cells and cancers of the gastric epithelium. Int J Mol Sci 16, 19153-19169.

Kelly, O.G., Chan, M.Y., Martinson, L.A., Kadoya, K., Ostertag, T.M., Ross, K.G., Richardson, M., Carpenter, M.K., D’Amour, K.A., Kroon, E., Moorman, M., Baetge, E.E., and Bang, A.G. (2011). Cell-surface markers for the isolation of pancreatic cell types derived from human embryonic stem cells. Nat Biotechnol 29, 750-756.

Kitamura, Y.I., Kitamura, T., Kruse, J.P., Raum, J.C., Stein, R., Gu, W., and Accili, D. (2005). FoxO1 protects against pancreatic $\beta$ cell failure through NeuroD and MafA induction. Cell Metab 2, 153-163.

Klein, D., Álvarez-Cubela, S., Lanzoni, G., Vargas, N., Prabakar, K.R., Boulina, M., Ricordi, C., Inverardi, L., Pastori, R.L., and Domínguez-Bendala, J. (2015). BMP-7 induces adult human pancreatic exocrine-to-endocrine conversion. Diabetes 64, 4123-4134.

Kroon, E., Martinson, L.A., Kadoya, K., Bang, A.G., Kelly, O.G., Eliazer, S., Young, H., Richardson, M., Smart, N.G., Cunningham, J., Agulnick, A.D., D'Amour, K.A., Carpenter, M.K., and Baetge, E.E. (2008). Pancreatic endoderm derived from human embryonic stem cells generates glucose-responsive insulin-secreting cells in vivo. Nat Biotechnol 26, 443-452.

Lee, J., Sugiyama, T., Liu, Y., Wang, J., Gu, X., Lei, J., Markmann, J.F., Miyazaki, S., Miyazaki, J., Szot, G.L., Bottino, R., and Kim, S.K. (2013). Expansion and conversion of human pancreatic ductal cells into insulinsecreting endocrine cells. ELife 2, e00940.

Lemper, M., De Groef, S., Stangé, G., Baeyens, L., and Heimberg, H. (2016). A combination of cytokines EGF and CNTF protects the functional beta cell mass in mice with short-term hyperglycaemia. Diabetologia 59, 1948-1958.

Li, W., Cavelti-Weder, C., Zhang, Y., Clement, K., Donovan, S., Gonzalez, G., Zhu, J., Stemann, M., Xu, K., Hashimoto, T., Yamada, T., Nakanishi, M., Zhang, Y., Zeng, S., Gifford, D., Meissner, A., Weir, G., and Zhou, Q. (2014). Long-term persistence and development of induced pancreatic beta cells generated by lineage conversion of acinar cells. Nat Biotechnol 32, 1223-1230.

Liu, H., Yang, H., Zhu, D., Sui, X., Li, J., Liang, Z., Xu, L., Chen, Z., Yao, A., Zhang, L., Zhang, X., Yi, X., Liu, M., Xu, S., Zhang, W., Lin, H., Xie, L., Lou, J., Zhang, Y., Xi, J., and Deng, H. (2014). Systematically labeling developmental stage-specific genes for the study of pancreatic $\beta$-cell differentiation from human embryonic stem cells. Cell Res 24, 1181-1200.

Maza, I., Caspi, I., Zviran, A., Chomsky, E., Rais, Y., Viukov, S., Geula, S., Buenrostro, J.D., Weinberger, L., Krupalnik, V., Hanna, S., Zerbib, M., Dutton, J.R., Greenleaf, W.J., Massarwa, R., Novershtern, N., and Hanna, J.H. (2015). Transient acquisition of pluripotency during somatic cell transdifferentiation with iPSC reprogramming factors. Nat Biotechnol 33, 769-774.

Meivar-Levy, I., Sapir, T., Berneman, D., Weissbach, T., Polak-Charcon, S., Ravassard, P., Tzakis, A.G., Mor, E., Ricordi, C., and Ferber, S. (2011). Human liver cells expressing albumin and mesenchymal characteristics give rise to insulin-producing cells. J Transplant 2011, 1-12.

Merani, S., Toso, C., Emamaullee, J., and Shapiro, A.M.J. (2008). Optimal implantation site for pancreatic islet transplantation. Br J Surg 95, 1449-1461.

Mills, J.C., and Shivdasani, R.A. (2011). Gastric epithelial stem cells. Gastroenterology 140, 412-424.

Mojibian, M., Lam, A.W.Y., Fujita, Y., Asadi, A., Grassl, G.A., Dickie, P.,
Tan, R., Cheung, A.T., and Kieffer, T.J. (2014). Insulin-producing intestinal $\mathrm{K}$ cells protect nonobese diabetic mice from autoimmune diabetes. Gastroenterology 147, 162-171.e6.

Nair, G., and Hebrok, M. (2015). Islet formation in mice and men: lessons for the generation of functional insulin-producing $\beta$-cells from human pluripotent stem cells. Curr Opin Genets Dev 32, 171-180.

Nostro, M.C., and Keller, G. (2012). Generation of beta cells from human pluripotent stem cells: potential for regenerative medicine. Seminars Cell Dev Biol 23, 701-710.

Nostro, M.C., Sarangi, F., Ogawa, S., Holtzinger, A., Corneo, B., Li, X., Micallef, S.J., Park, I.H., Basford, C., Wheeler, M.B., Daley, G.Q., Elefanty, A.G., Stanley, E.G., and Keller, G. (2011). Stage-specific signaling through TGF $\beta$ family members and WNT regulates patterning and pancreatic specification of human pluripotent stem cells. Development 138, 861-871.

Nostro, M.C., Sarangi, F., Yang, C., Holland, A., Elefanty, A.G., Stanley, E.G., Greiner, D.L., and Keller, G. (2015). Efficient generation of NKX6- $1^{+}$pancreatic progenitors from multiple human pluripotent stem cell lines. Stem Cell Rep 4, 591-604.

Pagliuca, F.W., Millman, J.R., Gürtler, M., Segel, M., Van Dervort, A., Ryu, J.H., Peterson, Q.P., Greiner, D., and Melton, D.A. (2014). Generation of functional human pancreatic $\beta$ cells in vitro. Cell 159, 428-439.

Pepper, A.R., Gala-Lopez, B., Pawlick, R., Merani, S., Kin, T., and Shapiro, A.M.J. (2015). A prevascularized subcutaneous device-less site for islet and cellular transplantation. Nat Biotechnol 33, 518-523.

Quaranta, P., Antonini, S., Spiga, S., Mazzanti, B., Curcio, M., Mulas, G., Diana, M., Marzola, P., Mosca, F., Longoni, B., and Chatenoud, L. (2014). Co-transplantation of endothelial progenitor cells and pancreatic islets to induce long-lasting normoglycemia in streptozotocin-treated diabetic rats. PLoS ONE 9, e94783.

Rahier, J., Guiot, Y., Goebbels, R.M., Sempoux, C., and Henquin, J.C. (2008). Pancreatic $\beta$-cell mass in European subjects with type 2 diabetes. Diabetes Obes Metab 10, 32-42.

Gomez, D.L., O’Driscoll, M., Sheets, T.P., Hruban, R.H., Oberholzer, J., McGarrigle, J.J., Shamblott, M.J., and Rakonczay, Z. (2015). Neurogenin 3 expressing cells in the human exocrine pancreas have the capacity for endocrine cell fate. PLoS ONE 10, e0133862.

Rekittke, N.E., Ang, M., Rawat, D., Khatri, R., and Linn, T. (2016). Regenerative therapy of type 1 diabetes mellitus: from pancreatic islet transplantation to mesenchymal stem cells. Stem Cells Int 2016, 1-22.

Rezania, A., Bruin, J.E., Arora, P., Rubin, A., Batushansky, I., Asadi, A., O'Dwyer, S., Quiskamp, N., Mojibian, M., Albrecht, T., Yang, Y.H.C., Johnson, J.D., and Kieffer, T.J. (2014). Reversal of diabetes with insulinproducing cells derived in vitro from human pluripotent stem cells. Nat Biotechnol 32, 1121-1133.

Rezania, A., Bruin, J.E., Riedel, M.J., Mojibian, M., Asadi, A., Xu, J., Gauvin, R., Narayan, K., Karanu, F., O'Neil, J.J., Ao, Z., Warnock, G.L., and Kieffer, T.J. (2012). Maturation of human embryonic stem cell-derived pancreatic progenitors into functional islets capable of treating preexisting diabetes in mice. Diabetes 61, 2016-2029.

Russ, H.A., Parent, A.V., Ringler, J.J., Hennings, T.G., Nair, G.G., Shveygert, M., Guo, T., Puri, S., Haataja, L., Cirulli, V., Blelloch, R., Szot, G.L., Arvan, P., and Hebrok, M. (2015). Controlled induction of human pancreatic progenitors produces functional beta-like cells in vitro. EMBO J 34, 1759-1772.

Sakata, N., Aoki, T., Yoshimatsu, G., Tsuchiya, H., Hata, T., Katayose, Y., Egawa, S., and Unno, M. (2014). Strategy for clinical setting in intramuscular and subcutaneous islet transplantation. Diabetes Metab Res Rev 30, 1-10.

Sangan, C.B., Jover, R., Heimberg, H., and Tosh, D. (2015). In vitro reprogramming of pancreatic alpha cells towards a beta cell phenotype following ectopic HNF4 $\alpha$ expression. Mol Cell Endocrinol 399, 50-59.

Sapir, T., Shternhall, K., Meivar-Levy, I., Blumenfeld, T., Cohen, H., Skutelsky, E., Eventov-Friedman, S., Barshack, I., Goldberg, I., Pri-Chen, S., Ben-Dor, L., Polak-Charcon, S., Karasik, A., Shimon, I., 
Mor, E., and Ferber, S. (2005). Cell-replacement therapy for diabetes: generating functional insulin-producing tissue from adult human liver cells. Proc Natl Acad Sci USA 102, 7964-7969.

Scharp, D.W., Swanson, C.J., Olack, B.J., Latta, P.P., Hegre, O.D., Doherty, E.J., Gentile, F.T., Flavin, K.S., Ansara, M.F., and Lacy, P.E. (1994). Protection of encapsulated human islets implanted without immunosuppression in patients with type I or type II diabetes and in nondiabetic control subjects. Diabetes 43, 1167-1170.

Scholin, A., Bjorklund, L., Borg, H., Arnqvist, H., Bjork, E., Blohme, G., Bolinder, J., Eriksson, J.W., Gudbjornsdottir, S., Nystrom, L., Ostman, J., Karlsson, A.F., and Sundkvist, G. (2004). Islet antibodies and remaining beta-cell function 8 years after diagnosis of diabetes in young adults: a prospective follow-up of the nationwide Diabetes Incidence Study in Sweden. J Intern Med 255, 384-391.

Schulz, T.C., Young, H.Y., Agulnick, A.D., Babin, M.J., Baetge, E.E., Bang, A.G., Bhoumik, A., Cepa, I., Cesario, R.M., Haakmeester, C., Kadoya, K., Kelly, J.R., Kerr, J., Martinson, L.A., McLean, A.B., Moorman, M.A., Payne, J.K., Richardson, M., Ross, K.G., Sherrer, E.S., Song, X., Wilson, A.Z., Brandon, E.P., Green, C.E., Kroon, E.J., Kelly, O.G., D'Amour, K.A., Robins, A.J., and Lynn, F.C. (2012). A scalable system for production of functional pancreatic progenitors from human embryonic stem cells. PLoS ONE 7, e37004.

Shapiro, A.M.J., Lakey, J.R.T., Ryan, E.A., Korbutt, G.S., Toth, E., Warnock, G.L., Kneteman, N.M., and Rajotte, R.V. (2000). Islet transplantation in seven patients with type 1 diabetes mellitus using a glucocorticoid-free immunosuppressive regimen. N Engl J Med 343, 230-238.

Shen, W., Tremblay, M.S., Deshmukh, V.A., Wang, W., Filippi, C.M., Harb, G., Zhang, Y., Kamireddy, A., Baaten, J.E., Jin, Q., Wu, T., Swoboda, J.G., Cho, C.Y., Li, J., Laffitte, B.A., McNamara, P., Glynne, R., Wu, X., Herman, A.E., and Schultz, P.G. (2013). Small-molecule inducer of $\beta$ cell proliferation identified by high-throughput screening. J Am Chem Soc 135, 1669-1672.

Shi, Y., and Hu, F.B. (2014). The global implications of diabetes and cancer. Lancet 383, 1947-1948.

Shiba, Y., Fernandes, S., Zhu, W.Z., Filice, D., Muskheli, V., Kim, J., Palpant, N.J., Gantz, J., Moyes, K.W., Reinecke, H., Van Biber, B., Dardas, T., Mignone, J.L., Izawa, A., Hanna, R., Viswanathan, M., Gold, J.D., Kotlikoff, M.I., Sarvazyan, N., Kay, M.W., Murry, C.E., and Laflamme, M.A. (2012). Human ES-cell-derived cardiomyocytes electrically couple and suppress arrhythmias in injured hearts. Nature 489, 322-325.

Takahashi, K., and Yamanaka, S. (2006). Induction of pluripotent stem cells from mouse embryonic and adult fibroblast cultures by defined factors. Cell 126, 663-676.

Takahashi, K., and Yamanaka, S. (2016). A decade of transcription factormediated reprogramming to pluripotency. Nat Rev Mol Cell Biol 17, 183-193.

Talchai, C., Xuan, S., Kitamura, T., DePinho, R.A., and Accili, D. (2012). Generation of functional insulin-producing cells in the gut by Foxol ablation. Nat Genet 44, 406-412.

Tang, D.Q., Cao, L.Z., Chou, W., Shun, L., Farag, C., Atkinson, M.A., Li, S.W., Chang, L.J., and Yang, L.J. (2006). Role of Pax4 in Pdx1-VP16mediated liver-to-endocrine pancreas transdifferentiation. Lab Invest 86 , 829-841.
Thomson, J.A., Itskovitz-Eldor, J., Shapiro, S.S., Waknitz, M.A., Swiergiel, J.J., Marshall, V.S., and Jones, J.M. (1998). Embryonic stem cell lines derived from human blastocysts. Science 282, 1145-1147.

Thorel, F., Népote, V., Avril, I., Kohno, K., Desgraz, R., Chera, S., and Herrera, P.L. (2010). Conversion of adult pancreatic $\alpha$-cells to $\beta$-cells after extreme b-cell loss. Nature 464, 1149-1154.

Vegas, A.J., Veiseh, O., Gürtler, M., Millman, J.R., Pagliuca, F.W., Bader, A.R., Doloff, J.C., Li, J., Chen, M., Olejnik, K., Tam, H.H., Jhunjhunwala, S., Langan, E., Aresta-Dasilva, S., Gandham, S., McGarrigle, J.J., Bochenek, M.A., Hollister-Lock, J., Oberholzer, J., Greiner, D.L., Weir, G.C., Melton, D.A., Langer, R., and Anderson, D.G. (2016). Long-term glycemic control using polymer-encapsulated human stem cell-derived beta cells in immune-competent mice. Nat Med 22, 306-311.

Wahoff, D.C., Hower, C.D., Sutherland, D.E., Leone, J.P., and Gores, P.F. (1994). The peritoneal cavity: an alternative site for clinical islet transplantation? Transplant Proc 26, 3297-3298.

Wang, Q., Wang, H., Sun, Y., Li, S.W., Donelan, W., Chang, L.J., Jin, S., Terada, N., Cheng, H., Reeves, W.H., and Yang, L.J. (2013). The reprogrammed pancreatic progenitor-like intermediate state of hepatic cells is more susceptible to pancreatic beta cell differentiation. J Cell Sci 126, 3638-3648.

Xie, R., Everett, L.J., Lim, H.W., Patel, N.A., Schug, J., Kroon, E., Kelly, O.G., Wang, A., D’Amour, K.A., Robins, A.J., Won, K.J., Kaestner, K.H., and Sander, M. (2013). Dynamic chromatin remodeling mediated by polycomb proteins orchestrates pancreatic differentiation of human embryonic stem cells. Cell Stem Cell 12, 224-237.

Xu, G., Stoffers, D.A., Habener, J.F., and Bonner-Weir, S. (1999). Exendin-4 stimulates both beta-cell replication and neogenesis, resulting in increased beta-cell mass and improved glucose tolerance in diabetic rats. Diabetes 48, 2270-2276.

Yang, Y.P., Thorel, F., Boyer, D.F., Herrera, P.L., and Wright, C.V.E. (2011). Context-specific $\alpha$ - to- $\beta$-cell reprogramming by forced Pdx 1 expression. Genes Dev 25, 1680-1685.

Yatoh, S., Akashi, T., Chan, P.P., Kaneto, H., Sharma, A., Bonner-Weir, S., and Weir, G.C. (2007). NeuroD and reaggregation induce $\beta$-cell specific gene expression in cultured hepatocytes. Diabetes Metab Res Rev 23, 239-249.

Zhang, L., Cao, Z., Bai, T., Carr, L., Ella-Menye, J.R., Irvin, C., Ratner, B.D., and Jiang, S. (2013). Zwitterionic hydrogels implanted in mice resist the foreign-body reaction. Nat Biotechnol 31, 553-556.

Zhao, Z., Abdolazimi, Y., Armstrong, N.A., and Annes, J.P. (2016). A highcontent in vitro pancreatic islet $\beta$-cell replication discovery platform. J Vis Exp doi: 10.3791/54298.

Zhao, Z., Low, Y.S., Armstrong, N.A., Ryu, J.H., Sun, S.A., Arvanites, A.C., Hollister-Lock, J., Shah, N.H., Weir, G.C., and Annes, J.P. (2014). Repurposing cAMP-modulating medications to promote $\beta$-cell replication. Mol Endocrinol 28, 1682-1697.

Zhou, Q., Brown, J., Kanarek, A., Rajagopal, J., and Melton, D.A. (2008). In vivo reprogramming of adult pancreatic exocrine cells to $\beta$-cells. Nature 455, 627-632.

Zhu, S., Russ, H.A., Wang, X., Zhang, M., Ma, T., Xu, T., Tang, S., Hebrok, M., and Ding, S. (2016). Human pancreatic beta-like cells converted from fibroblasts. Nat Commun 7, 10080.

Open Access This article is distributed under the terms of the Creative Commons Attribution License which permits any use, distribution, and reproduction in any medium, provided the original author(s) and source are credited. 